\title{
Area Under the Curve dan Akurasi Cystatin C untuk Diagnosis Acute Kidney Injury pada Pasien Politrauma
}

\author{
Tinni T. Maskoen, Djaya Purnama \\ Departemen Anestesiologi dan Terapi Intensif Fakultas Kedokteran Universitas Padjadjaran \\ Rumah Sakit Dr. Hasan Sadikin Bandung, Indonesia
}

\begin{abstract}
Abstrak
Pasien yang mengalami cedera dengan Injury Severity Score (ISS) $\geq 16$ didefinisikan sebagai politrauma. Pada politrauma terjadi hipoksia jaringan, autoregulasi terganggu, mikrosirkulasi glomerulus, cedera sel tubular serta proses inflamasi yang apabila tidak diatasi secara adekuat dapat menyebabkan acute kidney injury (AKI). Saat ini diagnosis AKI berdasar atas kenaikan kreatinin serum yang terdeteksi setelah terjadi kerusakan ginjal. Cystatin $\mathrm{C}$ merupakan penanda biologis yang dapat mendeteksi AKI. Tujuan penelitian ini adalah mengetahui nilai area under the curve (AUC) dan akurasi cystatin C untuk diagnosis AKI pada pasien politrauma di Instalasi Gawat Darurat (IGD) RSUP Dr. Hasan Sadikin Bandung. Penelitian uji diagnostik ini dengan analisis data sekunder pada sebagian data penelitian Academic Leadership Grant (ALG) pasien politrauma di IGD RSUP Dr. Hasan Sadikin Bandung dari Januari-Juni 2017. Analisis data menggunakan kurva receiver operating characteristic (ROC) dengan program statistical product and service solution (SPSS)versi 24.0 for windows. Hasil penelitian dari 23 sampel menunjukkan pada cut-off point $354,97 \mathrm{ng} / \mathrm{mL}$ cystatin C plasma memiliki sensitivitas $100 \%$, spesifisitas $88,9 \%$, nilai duga positif 71,4\%; nilai duga negatif 100\%; nilai AUC 0,967; dan akurasi 91,3\%. Simpulan penelitian ini adalah nilai AUC dan akurasi cystatin $\mathrm{C}$ memberikan hasil yang baik dalam diagnosis AKI pada pasien politrauma.
\end{abstract}

Kata kunci: Acute kidney injury, akurasi, cystatin C, nilai AUC, politrauma

\section{Area Under the Curve and Cystatin C Accuracy for Acute Kidney Injury Diagnosis in Polytrauma Patients}

\begin{abstract}
Patients experiencing injuries with an Injury Severity Score (ISS) of $>16$ are defined as polytrauma patients. Polytrauma can cause hypoxia, disruption of autoregulation, glomerular microcirculation, tubular cell injury, and inflammation processes that, without adequate treatment, may lead to acute kidney injury (AKI). The current diagnosis of AKI is based on the elevated serum creatinine that can be detected after kidney damage. Cystatin $\mathrm{C}$ is a biomarker that can detect AKI. The aim of this study was to determine the value of area under the curve (AUC) and accuracy of cystatin C for diagnosing AKI in polytrauma patients in the Emergency Room (ER) of Dr. Hasan Sadikin Bandung. A diagnostic test study using secondary data from theAcademic Leadership Grant (ALG) study onpolytrauma patients in the ER of Dr. Hasan Sadikin General Hospital Bandung, from January 2017-June 2017 was performed. Data was analyzed using the receiver operating characteristic (ROC) curve with statistical product and service solution (SPSS) version 24.0 for windows. Results from 23 samples showed that the cut off point of plasma cystatin $\mathrm{C}$ was $354.97 \mathrm{ng} / \mathrm{mL}$ with a sensitivity of $100.0 \%$, specificity of $88.9 \%$, positive predictive value of $71.4 \%$, negative value of $100.0 \%$, AUC value of 0.967 and accuracy of $91.3 \%$. Hence, the AUC values and cystatin $\mathrm{C}$ accuracy present good results for diagnosing AKI in polytrauma patients.
\end{abstract}

Key words: Accuracy, acute kidney injury, cystatin C, the value of AUC, polytrauma

Korespondensi: Dr. Tinni T. Maskoen, dr., SpAn-KIC, KMN, M.Kes, Departemen Anestesiologi dan Terapi Intensif Fakultas Kedokteran Universitas Padjadjaran/Rumah Sakit Dr. Hasan Sadikin Bandung, Jalan Pasteur No. 38 Bandung, Jawa Barat 40161 Email: ttmaskoen@yahoo.co.id 


\section{Pendahuluan}

Trauma merupakan masalah kesehatan setiap negara di seluruh dunia yang menyebabkan lebih dari 5 juta kematian per tahun atau 16.000 kematian setiap hari berdasar atas laporan World Health Organization (WHO) tahun 2013. Kecelakaan lalu lintas khususnya kendaraan bermotor merupakan penyebab terbanyak kematian dari seluruh dunia. ${ }^{1-3}$ Terdapat dua atau lebih cedera berat dengan setidaknya satu atau jumlah dari keseluruhan cedera tersebut yang dapat mengancam kehidupan disebut politrauma. ${ }^{4}$ Studi lain menggunakan penilaian yang lebih objektif dengan mendefinisikan politrauma menggunakan Injury Severity Score (ISS) $\geq 16$. Perhitungan skor keparahan trauma dapat menggunakan ISS yang merupakan sistem penilaian anatomi yang mewakili seluruh penilaian pada pasien dengan politrauma. ${ }^{5}$

Pada politrauma terjadi hipoksia, gangguan autoregulasi, mikrosirkulasi glomerolus, peritubular, cedera sel tubulus, cedera endotel, trombosis mikrovaskular, dan shunt arteri vena, akibatnya terjadi aktivasi proses inflamasi. Acute kidney injury (AKI) dimasukkan dalam kondisi inflamasi. Banyak mediator inflamasi dan antiinflamasi telah diidentifikasi untuk AKI ${ }^{6,7}$ Keadaan tersebut terjadi pada politrauma disebabkan oleh karena cedera sistemik akibat perdarahan yang banyak dari intraabdominal dan politrauma pada tulang atau akibat pneumotoraks, hematotoraks,, dan dapat juga akibat sumbatan jalan napas karena koma atau trauma. Hipovolemia dan hipoksia yang tidak diatasi dengan adekuat akan menyebabkan penurunan pengantaran oksigen ke jaringan sehingga dapat menyebabkan disfungsi beberapa organ termasuk ginjal sehingga terjadi AKI. ${ }^{7}$ Pasien politrauma yang dirawat di rumah sakit mengalami kejadian AKI sekitar 0,098-8,4\% dengan angka mortalitas 7-83\% dari seluruh populasi pasien trauma. ${ }^{8}$

Berdasar atas acute dialysis quality initiative (ADQI) terdapat sistem klasifikasi AKI dengan kriteria risk injury fail loss end stage (RIFLE) yang terdiri atas tiga kategori berdasar atas kreatinin serum dan laju filtrasi glomerulusatau urine output serta dua kategori yang menggambarkan prognosis ginjal. ${ }^{8,9}$

Peningkatan kadar kreatinin serum dan penurunan laju filtrasi glomerulus tidak selalu mengikuti progresivitas kerusakan tubulus ginjal. Beberapa faktor di luar ginjal, yaitu makanan, jenis kelamin, dan massa otot dapat memengaruhi kreatinin serum dan menyebabkan sensitivitas kreatinin serum untuk deteksi AKI menjadi rendah. Dengan terdapat berbagai faktor tersebut maka diperlukan suatu penanda biologis yang lebih baik untuk mendeteksi penurunan fungsi ginjal. ${ }^{10-12}$

Penanda biologis yang diharapkan dapat mendiagnosis AKI, yaitu spesifik untuk ginjal dengan nilai sensitivitas dan spesifisitas yang tinggi, memiliki area under the curve (AUC) serta akurasiyang baik dalam mendiagnosis AKI. ${ }^{13}$ Berbagai penelitian penanda biologis telah dilakukan untuk mendeteksi AKI lebih awal seperti cystatin C, kidney injury molecule-1 (KIM-1), neutropil gelatinase associated lipocalin (NGAL), interleukin-18 (IL-18), dan liver fatty acid binding protein (L-FABP). ${ }^{12}$

Cystatin C adalah inhibitor sistein protease dengan berat molekul $13 \mathrm{kd}$ yang disintesis dan dilepaskan ke dalam darah secara relatif konstan oleh semua nukleus sel, mengalami filtrasi glomerulus secara bebas, dan diabsorbsi secara lengkap dan tidak disekresikan di tubulus proksimal. Cystatin $\mathrm{C}$ bekerja pada fungsi filtrasi glomerulus dan terdeteksi lebih baik dalam serum dibanding dengan di dalam urin, cystatin C mendeteksi perkembangan AKI lebih awal daripada kreatinin serum berdasar atas kriteria RIFLE dan juga kenaikan yang cepat dibanding dengan dengan kreatinin serum.

Perubahan kadar cystatin C lebih cepat setelah perubahan fungsi ginjal dan juga mendiagnosis AKI lebih awal daripada kreatinin serum. Cystatin C serum dapat meningkat lebih dari $50 \%$ pada awal kejadian AKI dibanding dengan dengan kreatinin serum. ${ }^{14}$

Tujuan penelitian ini adalah mengetahui nilai AUC dan akurasi cystatin C untuk diagnosis AKI pada pasien politrauma di IGD Rumah Sakit Dr. Hasan Sadikin Bandung (RSUP).

\section{Metode}

Penelitian uji diagnostik ini mempergunakan data sekunder dengan rancangan studi potong lintang. Objek penelitian ini terdiri atas 23 data jumlah sampel yang didapatkan dari rumus penelitian diagnostik dengan hasil keluaran nilai AUC. Besar sampel ditentukan berdasar atas taraf kepercayaan 95\%, nilai referensi AUC yang diharapkan sebesar 0,7 dan 0,95. ${ }^{16}$

Data sampel ialah meliputi sebagian data penelitian Academic Leadership Grant (ALG) dengan judul "Faktor prognostik NGAL, cystatin C, KIM-1, IL-18 dan pCO2 gap terhadap kejadian AKI dan mortalitas pada pasien politrauma di 
emergensi RSUP Dr. Hasan Sadikin Bandung, dari bulan Januari-Juni 2017 yang memenuhi kriteria inklusi dan tidak termasuk eksklusi. Dana penelitian bersumber dari ALG. Kriteria inklusi penelitian ini adalah pasien politrauma, usia 18-65 tahun, ISS $\geq 16$, nilai CVP $\geq 10$ $\mathrm{cmH}_{2} \mathrm{O}$ serta terdapat data nilai cystatin $\mathrm{C}$ dan kreatinin serum. Kriteria eksklusi adalah pasien yang ketika dilakukan anamnesis memiliki chronic kidney disease (CKD) dengan riwayat hemodialisis, penyakit keganasan, kelainan jantung kronik, dan diabetes melitus. Data penelitian ALG yang tidak lengkap merupakan kriteria pengeluaran penelitian ini.

Penelitian ini dilaksanakan pada bulan Januari-Februari 2018 setelah peneliti utama ALG dan Komite Etik Penelitian Kesehatan Fakultas Kedokteran Universitas Padjadjaran/ RSUP Dr. Hasan Sadikin Bandung memberikan persetujuan penggunaan data. Pada data primer dengan kode etik LB.04.01/A05/ EC/042/1/2016 dan data sekunder dengan persetujuan pengunaan data oleh peneliti ALG, kemudian dilakukan pengambilan sebagian data penelitian ALG pada pasien politrauma di IGD RSUP Dr. Hasan Sadikin Bandung dari bulan Januari-Juni 2017. Dilakukan pencatatan meliputi usia, jenis kelamin, ISS, mekanisme trauma, nilai CVP, serta nilai kreatinin dan nilai cystatin C. Setelah mendapatkan data, peneliti melakukan uji statistik untuk menghitung sensitivitas,spesifisitas, nilai duga positif, nilai duga negatif, nilai AUC, dan akurasi pemeriksaan cystatin $\mathrm{C}$ untuk diagnosis AKI.

Area under the curve (AUC) adalah suatu daerah di bawah receiver operating characteristic (ROC). Receiver operating characteristic (ROC) merupakan kurva yang dihasilkan dari tarik ulur antara sensitivitas dan spesifisitas pada berbagai titik potong. Nilai AUC secara teoritis berada di antara 0 dan 1 . Nilai AUC memberikan gambaran tentang keseluruhan pengukuran atas kesesuaian dari model yang digunakan. Semakin besar area under curve maka semakin baik variabel yang diteliti dalam memprediksi kejadian. ${ }^{16}$

Penelitian uji diagnostik akan semakin baik bila nilai AUC mendekati 1. Kriteria interpretasi nilai AUC adalah sebagai berikut: $>0,5-0,6=$ sangat lemah, $>0,6-0,7=$ lemah, $>0,7-0,8=$ sedang, $>0,8-0,9=$ baik, $>0,9-1=$ sangat baik. ${ }^{15}$ Kriteria interpretasi kategori nilai akurasi adalah sebagai berikut: nilai $50-60 \%$ (sangat lemah), $60-70 \%$ (lemah), 70-80\% (sedang), 80-90\% (kuat), dan 90-100\% (sangat kuat). ${ }^{16}$

Pengolahan uji statistik terhadap data dilakukan melalui program memakai statistical product and service solution (SPSS) versi 24.0 for windows.

\section{Hasil}

Didapatkan total data penelitian sebanyak 23 sampel. Tidak ada data yang dikeluarkan. Karakteristik pasien penelitian berusia rerata $31,30 \pm 11,125$ tahun, jenis kelamin laki-laki lebih banyak dibanding dengan dengan perempuan, mekanisme trauma terbanyak disebabkan oleh kecelakaan lalu lintas, ISS rerata 21,86 $\pm 5,083$ dan nilai CVP rerata $14,17 \pm 1,402$ (Tabel 1). Pada penelitian ini didapatkan 5 dari 23 sampel didiagnosis AKI berdasar atas kriteria RIFLE dengan nilai cut-off kreatinin serum adalah 1,3 $\mathrm{mg} / \mathrm{dL}$, dan dihitung nilai cystatin $c$ berdasar atas cut-off nilai kreatinin serum sehingga nilai cut-off cystatin $\mathrm{C}$ pada penelitian ini ditentukan oleh nilai rerata atau mean dari nilai cystatin $\mathrm{C}$

Tabel 1 Karakteristik Umum Pasien

\begin{tabular}{|c|c|}
\hline Variabel & $n=23$ \\
\hline \multicolumn{2}{|l|}{ Usia } \\
\hline Mean \pm Standar deviasi & $31,30 \pm 11,125$ \\
\hline Median & 32,000 \\
\hline $\begin{array}{l}\text { Range (minimal- } \\
\text { maksimal) }\end{array}$ & $17,00-57,00$ \\
\hline \multicolumn{2}{|l|}{ Jenis kelamin } \\
\hline Laki-laki & 22 \\
\hline Perempuan & 1 \\
\hline \multicolumn{2}{|l|}{ Mekanisme trauma } \\
\hline Kecelakaan lalu lintas & 18 \\
\hline Jatuh dari ketinggian & 3 \\
\hline Tertimpa besi/reruntuhan & 2 \\
\hline \multicolumn{2}{|l|}{ ISS } \\
\hline Mean \pm Standar deviasi & $21,86 \pm 5,083$ \\
\hline Median & 22,000 \\
\hline $\begin{array}{l}\text { Range (minimal- } \\
\text { maksimal) }\end{array}$ & $17,00-38,00$ \\
\hline \multicolumn{2}{|l|}{ CVP } \\
\hline Mean \pm Std & $14,17 \pm 1,402$ \\
\hline Median & 14,000 \\
\hline $\begin{array}{l}\text { Range (minimal- } \\
\text { maksimal) }\end{array}$ & $12,00-17,00$ \\
\hline \multicolumn{2}{|c|}{$\begin{array}{l}\text { Keterangan: untuk data kategorik disajikan dengan } \\
\text { jumlah/frekuensi dan persentase, sedangkan data } \\
\text { numerik disajikan dengan rerata, median, standar } \\
\text { deviasi, dan range. ISS: injury severity score, CVP } \\
\text { central venous pressure. }\end{array}$} \\
\hline
\end{tabular}


Tabel 2 Kadar dan Nilai Cut off Cystatin C pada Pasien AKI + berdasar atas RIFLE (Kreatinin $\geq 1,3$ )

\begin{tabular}{ccc}
\hline Kreatinin $(\mathbf{m g} / \mathbf{d L})^{*}$ & ${\text { Cystatin C }(\mathbf{n g} / \mathbf{m L})^{* *}}^{\text {Cut-off Cystatin C }}$ \\
\hline 1,39 & 365,15 & \\
1,4 & 384,35 & \\
1,44 & 411,3 & $354,97^{* * *}$ \\
1,6 & 592,55 & \\
2,2 & 1054,9 & \\
\hline
\end{tabular}

Keterangan: * nilai kreatinin berdasar atas kriteria RIFLE; **nilai cystatin C pada sampel AKI, ***nilai cut-off cystatin C

Tabel 3 Uji Diagnostik AKI

\begin{tabular}{|c|c|c|c|}
\hline \multirow{2}{*}{$\begin{array}{l}\text { Kadar Cystatin C } \\
(\geq 354,97 \mathrm{ng} / \mathrm{mL})\end{array}$} & \multicolumn{2}{|c|}{ Kadar Kreatinin $(\geq 1,3 \mathrm{mg} / \mathrm{dL})$} & \multirow{2}{*}{$\begin{array}{c}\text { Total } \\
\text { (n) }\end{array}$} \\
\hline & $\underset{n=5}{\mathrm{AKI}+}$ & $\begin{array}{l}\text { AKI - } \\
n=18\end{array}$ & \\
\hline $\mathrm{AKI}+$ & 5 & 2 & 7 \\
\hline AKI - & 0 & 16 & 16 \\
\hline
\end{tabular}

pada sampel AKI yang berdasar atas kriteria RIFLE, yaitu 354,97ng/mL.

Tabel 3 menunjukkan angka kejadian AKI pada pasien politrauma yang masuk ke IGD berdasar atas pada kenaikan kadar kreatinin serum mempergunakan kriteria RIFLE dan peningkatan kadar cystatin $C$. Kejadian AKI berdasar atas kriteria RIFLE didapatkan 5 dari 23 sampel, sedangkan angka kejadian AKI berdasar atas peningkatan kadar cystatin C lebih banyak, yaitu 7 dari 23 sampel .

Nilai sensitivitas, spesifisitas, nilai duga positif (NDP), nilai duga negatif (NDN), area under the curve (AUC), dan akurasi cystatin $\mathrm{C}$ dianalisis menggunakan kurva receiver operating characteristic (ROC) dengan SPSS versi 24.0 for windows. Kurva receiver operating characteristic (ROC) menunjukkan bahwa cystatin $\mathrm{C}$ berdasar

\begin{tabular}{|c|c|}
\hline Uji Diagnostik & Nilai Diagnostik \\
\hline Sensitivitas & $100,0 \%$ \\
\hline Spesifisitas & $88,9 \%$ \\
\hline Nilai duga positif (NDP) & $71,4 \%$ \\
\hline Nilai duga negatif (NDN) & $100,0 \%$ \\
\hline $\begin{array}{l}\text { Area under the curve } \\
\text { (AUC) }\end{array}$ & 0,967 \\
\hline Akurasi & $91,3 \%$ \\
\hline
\end{tabular}

atas hasil mempunyai nilai diagnostik yang baik karena kurva menjauh dari garis 50\% dan mendekati $100 \%$ seperti pada Gambar dan Tabel 4.

\section{Pembahasan}

Berdasar atas Tabel 4, karakteristik umum pasien dengan melibatkan 23 pasien politrauma. Karakteristik sampel pada penelitian ini bersifat heterogen secara statistik, rerata usia berdasar

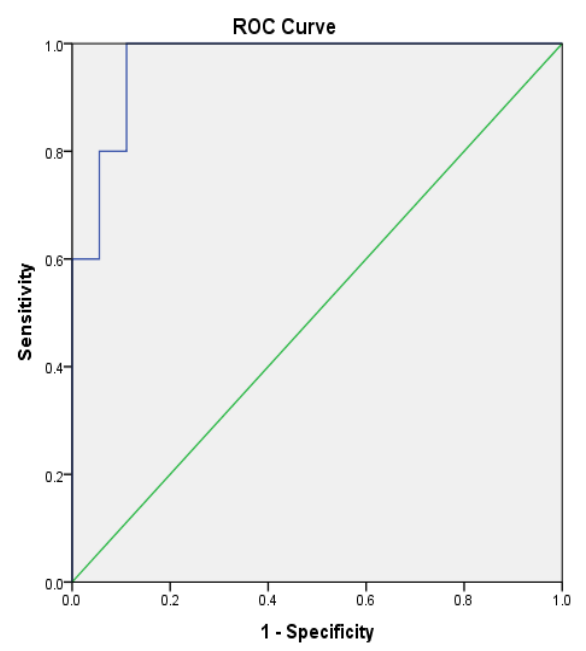

Gambar Kurva ROC Cystatin C 
atas tabel tersebut adalah 31,30 tahun, hasil tersebut sesuai dengan data WHO tahun 2013 yang menyatakan bahwa sebanyak 59\% korban kecelakaan lalu lintas berusia dewasa muda, yaitu 15-44 tahun.

Berdasar atas riset kesehatan dasar tahun 2013, kecelakaan lalu lintas 70\% adalah pengendara sepeda motor di Indonesia, yaitu pada usia produktif dengan rentang usia 15-59 tahun. ${ }^{16}$

Berdasar atas penelitian yang telah dilakukan, frekuensi tertinggi didapatkan pada kelompok laki-laki, yakni sebanyak 95,7\%. Hasil tersebut sesuai dengan riset kesehatan dasar tahun 2013 bahwa kejadian cedera frekuensi tertinggi pada kelompok laki-laki, yakni sebanyak 10,1\% dibanding dengan dengan kelompok perempuan $6,4 \%$. Keadaan ini disebabkan oleh banyaknya pengendara kendaraan bermotor dan pola perilaku berisiko tinggi pada laki-laki yang lebih besar. ${ }^{16}$ Trauma paling banyak pada rentang usia 25-34 tahun dan mekanisme trauma yang paling sering diakibatkan oleh kecelakaan lalu lintas pada transportasi darat, yaitu pengendara sepeda motor $56,6 \%$ dan transportasi darat lainnya 4,4\%, dibanding dengan jatuh dari ketinggian 25\% dan kejatuhan 2,4\% ${ }^{16}$ Penelitian berdasar atas riset kesehatan dasar sesuai dengan penelitian saat ini bahwa mekanisme trauma yang terbanyak disebabkan oleh kecelakaan lalu lintas, yakni sebanyak 78,3\% dibanding dengan dengan jatuh dari ketinggian $13 \%$ dan kejatuhan reruntuhan atau tertimpa besi $8,7 \%$. Karakteristik mekanisme trauma pada subjek penelitian ini juga sesuai dengan penelitian politrauma pusat trauma regional tingkat 1 di Taiwan bahwa mekanisme trauma yang terbanyak adalah karena kecelakaan lalu lintas pada pengendara sepeda motor. ${ }^{17}$

Nilai median ISS pada penelitian ini adalah 22 , hasil tersebut lebih rendah dibanding dengan dengan penelitian politrauma di pusat trauma regional tingkat 1 di Taiwan, yaitu 29 pada pasien politrauma dan nilai median ISS 26 . Tingginya nilai median ISS berdasar atas derajat beratnya trauma menyebabkan morbiditas dan mortalitas akibat trauma. ${ }^{17}$

Pada penelitian yang dilakukan di China, hasil sensitivitas dan spesifisitas $84 \%$ dan $82 \%$ untuk cystatin $\mathrm{C}$ serum dalam memprediksi terjadinya AKI, serta nilai area under the receiver operating characteristic curve (AUROC) sebesar $0,96 \cdot{ }^{17}$ Studi populasi yang dilakukan pada 198 pasien yang telah datang ke IGD Sant Andrea Hospital menyatakan bahwa nilai AUC untuk cystatin C mempunyai nilai prognostik yang baik dibanding dengan kreatinin serum, hal ini disebabkan oleh cystatin C diproduksi secara tetap oleh semua inti sel dan konsentrasinya tidak dipengaruhi oleh usia, jenis kelamin, tinggi badan, dan komposisi tubuh. ${ }^{18}$ Penelitian ini dilakukan pada seluruh pasien yang datang ke IGD yang meliputi tidak hanya pasien dengan diagnosis politrauma, pasien dalam penelitian sebelumnya lebih heterogen sehingga menjadi suatu keterbatasan dalam penelitian tersebut. Variabilitas yang luas pada data yang terukur dan memberikan hasil bahwa pengukuran cystatin C secara serial tidak memberikan nilai tambah untuk diagnosis AKI, sedangkan pada penelitian saat ini berbeda dengan penelitian lainnya karena dilakukan pada 23 pasien politrauma yang datang ke IGD RSUP Dr. Hasan Sadikin Bandung sehingga pengambilan sampel lebih sedikit dan untuk mengurangi variabilitas karakteristik pasien yang datang ke IGD RSUP Dr. Hasan Sadikin Bandung. Pada penelitian ini didapatkan nilai sensitivitas dan spesifisitas $100 \%$ dan 88,9\%, serta nilai AUROC sebesar 0,967 dengan nilai akurasi $91,3 \%$. Hasil penelitian ini berbeda dengan hasil penelitian lainnya karena jumlah sampel lebih sedikit dan karakteristik pasien hanya politrauma yang mengalami AKI sehingga nilai sensitivitas dapat mencapai $100 \%$ dan spesifisitas $88,9 \%$. Hasil penelitian ini juga menunjukkan bahwa nilai AUC dan akurasi di atas $\geq 80 \%$ yang berarti hasil pada penelitian ini cystatin $\mathrm{C}$ merupakan penanda biologis yang baik dalam memprediksi kejadian AKI. Hasil tersebut menjelaskan bahwa penggunaan cystatin C berdasar atas fungsi dari glomerular filtration rate, pengukuran cystatin $\mathrm{C}$ dapat digunakan untuk deteksi peningkatan resiko AKI yang tidak terdeteksi dengan perhitungan yang berdasar atas kreatinin. ${ }^{19}$ Cystatin $\mathrm{C}$ merupakan penanda laju filtrasi glomerulus yang lebih akurat karena beberapa penelitian telah menunjukkan bahwa cystatin C serum meningkat pada AKI sebelum terjadinya peningkatan kreatinin serum. ${ }^{20}$

Pada penelitian ini nilai cut-off point cystatin $\mathrm{C}$ untuk diagnosis AKI adalah 354,97 ng/dL, nilai tersebut didapatkan dari nilai rerata cystatin C pada kelompok AKI berdasar atas kriteria RIFLE. Kelompok AKI pada penelitian ini adalah subjek dengan kadar cystatin $\mathrm{C} \geq 354,97 \mathrm{ng} / \mathrm{mL}$, sedangkan kelompok non AKI merupakan subjek dengan kadar cystatin $\mathrm{C}<354,97 \mathrm{ng} / \mathrm{mL}$.

Hasil pemeriksaan cystatin C plasma pada pasien politrauma didapatkan nilai sensitivitas $100,0 \%$; spesifisitas $88,9 \%$; nilai duga positif 71,4\%; nilai duga negatif $100,0 \%$; nilai AUC 0,967; dan akurasi 91,3\%. 
Simpulan penelitian ini adalah cystatin $C$ dapat digunakan untuk mendiagnosis AKI pada pasien politrauma.

\section{Daftar Pustaka}

1. World Health Organization. Global status report on road safety; Pembaharuan 2015. [diunduh 20 Agustus 2017]. Tersedia dari: http://www.who.int/gho/road_safety/ mortality/number/en/.

2. Evans JA, van Essem KJP, McDougall D, Lee KA, Lyons T, Balogh ZJ. Epidemiology of traumatics deaths: comprehensive population based assessment. World J Surg. 2010;34(1):158-63.

3. Gad MA, Saber A, Farrag S, Shams ME, Ellabban GM. Incidence, patterns and factor predicting mortality of abdominal injury in trauma patient. N Am J Med Sci. 2012;4(3):1293-4.

4. Butcher NE, Balogh ZJ. Update on the definition of polytrauma. J Trauma Acute Care Surg. 2014;70(1):107- 11.

5. Butcher NE, Enninghost N, Sisak K, Balogh ZJ. The definition of polytrauma: variable interrater versus intrater agreement a prospective international study among trauma surgeons. J Trauma Acute Care Surg. 2013;73(3):884-9.

6. Jo SM, Daher EF. Acute kidney injury after trauma: Prevalence, clinical characteristics and RIFLE classification. Indian J Crit Care Med. 2010;14:121-8.

7. Dirac PA. Acute kidney injury. Dalam: Marino $\mathrm{P}$, penyunting. The ICU book. Edisi ke-4. Philadelphia: Lippincot, Williams \& Wilkins; 2014. hlm. 602-18.

8. De Abreu KS, Silva GB, Barreto AG, Melo FM, Oliveira BB, Mota RM, dkk. Acute kidney injury after trauma: prevalence, clinical characteristics and RIFLE classification. Indian J Crit Care Med. 2010;14:121-8.

9. Sharfuddin AA, Weisbord SD, Palevsky PM, Molitoris BA. Acute kidney injury. Dalam: Skorecki K, Chertow GM, Marsden PA, Taal
MW, Yu ASL, penyunting. Brenner and Rector's the kidney. Edisi ke-10. Philadelphia, PA: Elsevier; 2016. hlm. 958-1011.

10. Bagshaw SM, George C, Bellomo R. ANZICS Database Management Committee. A comparison of the RIFLE and AKIN criteria for acute kidney injury in critrically ill patient. Nephrol Dial Transport. 2008;23(5):156974.

11. Basile D, Anderson M, Sutton T. Pathophysiology of acute kidney injury. Compr Physiol. 2012;2(2):13031-353.

12. Han WK. Biomarker for early detection of acute kidney injury. Current Biomarker Findings. 2012;1:77-85.

13. Edelstein CL. Biomarkers of acute kidney injury. Adv Chronic Kidney Dis. 2008;15(3): 222-34.

14. Urbschat A, Obermuller N, Haferkamp A. Biomarkers kidney injury. Biomarkers J. 2011;16(1):22-30.

15. Dahlan MS. Penelitian diagnostik: dasardasar teoritis dan aplikasi dengan program SPSS dan Stata. Jakarta: Salemba Medika. 2009.

16. Balitbang Kemenkes RI. Riset kesehatan dasar; RISKESDAS. Jakarta: Balitbang Kemenkes RI; 2013.

17. Oyeniyi BT, Fox EE, Scerbo M, Tomasek JS, Wade CE, Holcomb JB. Trends in 1029 trauma death at level 1 trauma centre: impact of a bleeding control bundle of care. Injury. 2017;48(1):5-12.

18. Zhang Z, Lu B, Sheng X, Jin J. Cystatin C in prediction of acute kidney injury: a Systemic review and meta-analysis. Am J Kidney Dis. 2012;59(4):590-2.

19. Soto K, Coelho S, Rodrigues B, Martins H, Frade F, Lopes S, dkk. Cystatin C as a marker of acute kidney injury in the emergency department. Clin J Am Soc Nephrol. 2010; 5(10):1745-54.

20. Herget-Rosenthal S, Marggraf G, Husing J, Goring F, Pietruck F, Janssen 0, dkk. Early detection of acute renal failure by serum cystatin C. Kidney Int. 2004;66(3):1115-22.. 